\title{
Timber Market Liberalization in Sri Lanka: Implications for Forest Conservation
}

\author{
Jeevika Weerahewa and H.M. Gunatilake*
}

\begin{abstract}
This paper examines the impact of timber trade liberalisation on economic welfare and forest conservation in Sri Lanka. A partial equilibrium market simulation model was used to analyse the welfare impacts. Results show that removal of all border charges reduce timber price by about $25 \%$. Decline in timber price reduces the incentives for illegal logging and enhances forest conservation in Sri Lanka. The price reduction also results in an increase of consumer surplus by about US $\$ 40$ million per year. Timber trade liberalisation reduces local supply by about $12 \%$ to $31 \%$ depending on the elasticity of supply. The reduction of local supply can prevent 6,985, 13,971 and 17,469 ha of deforestation under the inelastic, unitary elastic and elastic demand and supply assumptions, respectively.
\end{abstract}

\section{Introduction}

Eighty percent of the total land area (6.56 million ha) of Sri Lanka was covered with closed-canopy natural forests in the beginning of the last century. This forest cover has dwindled to about $18 \%$ by 1992 (MFE, 1995). The annual rate of deforestation during 1956 - 1992 period was more than 40,000 ha while average annual replanting during the same period was only about 2,000 ha. The factors that contributed to deforestation and forest degradation in Sri Lanka are extensive and complex. Some of them are even outside the forestry sector. These factors include large agricultural and human settlement projects such as the Accelerated Mahaweli development project, shifting cultivation, excessive harvesting of timber and, perhaps harvesting of non-timber forest products. Of these causal factors, the potential for large scale agricultural expansion does not exist anymore. Shifting cultivation has been arrested successfully and it is not a major threat for natural forests today.

\footnotetext{
The authors are, respectively, Senior Lecturer, Department of Agricultural Economics and Business Management, Faculty of Agriculture, University of Peradeniya, Sri Lanka, and Senior Economist, Economics and Research Department, Asian Development Bank, the Philippines.
} 
Harvesting forest products, especially timber, may be the most important factor that contribute to the current deforestation in Sri Lanka.

Conventional steps taken to resolve this type of situations include establishment of forest plantations by the government, enactment of more stringent regulation and timber trade liberalization. Establishment of forest plantation by the government is prohibitively costly (MFE, 1995). More legislation may not yield any favourable results as existing restrictive regulations themselves have failed to do so. Given this situation timber trade liberalization seems to be an important option to secure the timber demand of the country. Against this background, this study attempts to examine the impacts of timber trade liberalization on social welfare and forest conservation. Import Tariffs (10\%), Goods and Service Tax (12.5\%), and National Defense Levy (6.5\%) are the major distortions in the timber market in the recent past. The paper quantifies the impact of removal of these distortions on both social welfare and forest conservation. The rest of the paper is organized as follows. The second section presents the background details of deforestation in Sri Lanka. The third section present theoretical approach used in the analysis. The fourth section describes the corresponding empirical model. The fifth section presents the findings of the research and the final section discusses the policy implications.

\section{Deforestration in Sri Lanka}

In a predominantly agricultural country like Sri Lanka, there is a strong link between population growth and deforestation. More food is needed to feed /support the increasing population. Agricultural production, in the last five decades, has been increased mainly by expanding the area under cultivation (MFE, 1995). In addition to the demand for food, demand for fuelwood, construction wood and other wood-based products are also increasing with population growth. The resource base that supplies forest products has declined remarkably; per capita forest area has declined from about 1.3 ha in 1900 to less than 0.1 ha in 1992 . The remaining natural forests are faced with increasing pressures as the population keeps on increasing (MFE, 1995).

Sri Lanka contributes to the global wealth of genetic materials and biodiversity by harbouring important tropical rainforests (Kotagama et al., 1997). However, the above-described deforestation and other development activities fragmented important forests with high biodiversity and only small 
patches of them remain today. Of the remaining natural high canopy forests, about $85 \%$ are dry-zone forest types. Ecologically more important lowland rainforests and montane forests are confined to small patches (Gunatilleke and Gunatilleke, 1991). Rich biological diversity and higher level of endemism found in the later category of forests have made their protection a priority. The government has declared most of the remaining lowland rainforests and montane forests as protected areas having recognized the importance of these forests for biodiversity protection.

Since natural forests supply a range of multiple products and environmental services, consequences of rapid deforestation can be far reaching. Population growth, coupled with industrial development result in increasing demand for forest-based products. Population in Sri Lanka is still growing at a rate of $1.1 \%$ (Central Bank of Sri Lanka, 2006). Annual sawnwood consumption per 1000 persons in 1993 was estimated to be $31 \mathrm{~m}^{3}$ (MFE, 1995). This is comparatively lower than Malaysia $\left(216.9 \mathrm{~m}^{3}\right)$, Thailand $\left(67.4 \mathrm{~m}^{3}\right)$, Korea $\left(112 \mathrm{~m}^{3}\right)$, and USA $485 \mathrm{~m}^{3}$. Sawn-wood demand is projected to grow from 0.544 million $\mathrm{m}^{3}$ in 1993 to 0.885 million $\mathrm{m}^{3}$ in 2020, at a rate of $12600 \mathrm{~m}^{3}$ per year. Demand for plywood and other wood-based panels are predicted to increase, at rates of $2.8 \%$ and $3.5 \%$ respectively per year (MFE, 1995). As predicted by the Sri Lanka Forestry Sector Master Plan, if the current trends continue unchecked and wood imports are not promoted, the country will face an increasing shortage of sawn wood (see Figure 1).

Before the 1970s the total requirement of timber was obtained from natural forests. Excessive harvesting of timber and clearing forests for agricultural expansion left only a small proportion of natural high canopy forests and they were also highly degraded. As mentioned earlier, some of the remaining important forests were designated as protected forests. Harvesting timber from unprotected forests was also banned. As a result of the ban people started substituting less preferred tree species, which grow in homegardens and other private lands, in place of the high-value tropical timber species. Private lands were supplying the timber requirement for a while and in the meantime, very restrictive regulations for felling and transporting timber were enacted. These regulations created an artificial scarcity of timber. Together with the growing scarcity, timber prices went up substantially. However, due to the uncertainty of getting timber permits to sell timber, private sector's involvement in timber tree cultivation has been 
minimal. This further aggravated the timber scarcity in the country (Senaviratne and Gunatilake, 2001).

Figure 1: $\quad$ Projected sawn wood production and consumption for Sri Lanka

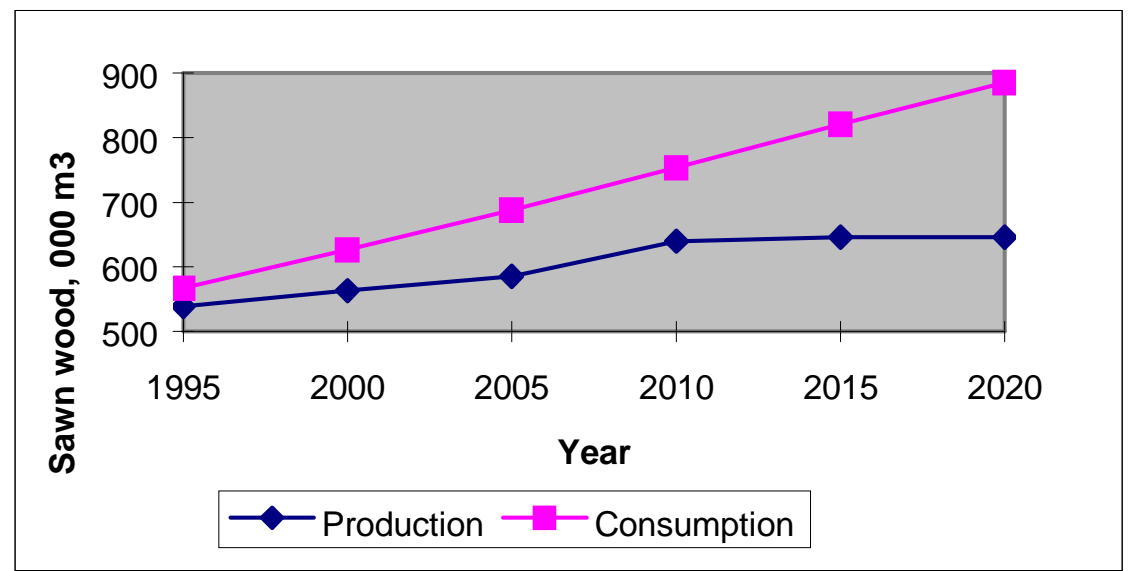

Source: MFE, 1995.

The higher prices of timber provide incentives for illegal logging from natural forests. For example, if a rural daily wage-worker can harvest a matured high value tropical timber tree from a natural forest, he/she could make more money than he/she would have earned as wages. Illegal timber extraction from natural forests is widespread because of such financial incentives. For example, the number of forest offences recorded in 2000 was 4,626. In 2001 this figure decreased by $3 \%$ to 4,344 and the value of illegal timber detected was Rs. 58.0 million (Central Bank of Sri Lanka, 2001). These records represent only a fraction of the illegal logging activities, as the illegal logging done with the support of relevant authorities are rarely brought within the system of justice.

While illegal logging is taking place, the heavy regulatory measures have lead to the emergence of a privileged and an influential group of timber traders. Timber traders and the government officers who are involved in issuing timber permits have formed a co-operative cartel to get the advantage of the situation. Under this arrangement the traders who are in the cartel will easily obtain timber permits, while others find it extremely difficult to obtain timber permits. In return for the support given to timber traders, government 
officers get a share of the timber value for each permit issued. The existing system has provided a very powerful bargaining position for the timber traders when they negotiate price with tree owners. As a result, tree owners get only about $20 \%$ of the final value of timber. Thus, existing heavy regulations have taken away the incentive to grow timber trees. On the other hand it has inflated the timber price by creating artificial scarcity of timber. The artificially high prices provide further incentives for illegal logging. Most of the timber trees available in private lands such as homegardens have been harvested by now. At present, some of the timber harvested from natural forests is also sent to the market as if they were harvested from private lands with the help of certain government officers. Thus, the heavy regulations have benefited neither consumers nor producers. They have not promoted conservation either (Senaviratne and Gunatilake, 2001).

As mentioned earlier, harvesting forest products from natural forests may be the most important factor that contributes to deforestation today. The impact of non-timber forest product (NTFP) extraction on forest degradation is not very clear. There is some evidence to suggest that excessive NTFP extraction leads to forest degradation (World Bank, 1993) while some other evidences show that in fact, NTFP used by local communities enhance forest conservation. While the issue is debatable, there is no concrete evidence in Sri Lanka to suggest that NTFP use by local communities is a major cause of deforestation. Under the above-described circumstance, illegal logging has become the major cause of deforestation in Sri Lanka. Given the above background, one of the major challenges that the country would be facing in the immediate future is supplying forest-based products, especially timber, without compromising the felt-need of conserving the remaining natural forests with high biodiversity values.

\section{Theoretical Framework}

A standard partial equilibrium framework for a small open economy is used for this analysis. Existence of perfectly competitive market is assumed except for the distortions that vary the world market and local prices. The demand for sawn wood is given by, $\mathrm{D}=\mathrm{f}\left(\mathrm{P}_{\mathrm{d}}\right)$ where $\mathrm{D}$ is demand and $\mathrm{P}_{\mathrm{d}}$ is domestic price. Supply of sawn wood is given by, $S=g\left(P_{d}\right)$ where $S$ is local supply. Excess demand is fulfilled by imports; imports=D-S. World market price of sawn wood $\left(\mathrm{P}_{\mathrm{w}}\right)$ is different from the domestic prices as there are 
border chargers such as tariff, goods and services tax (GST) and national defense levy (NDL).

$$
\begin{aligned}
& P_{d}=P_{W}+\text { Tariff }+ \text { GST }+N D L \\
& \text { Tariff }=P_{W} * \text { Tariff } \% \\
& G S T=\left(P_{W}+\text { Tariff }\right) * G S T \% \\
& N D L=\left(P_{W}+\text { Tariff }\right) * 125 \% * N D L \%
\end{aligned}
$$

Equation (1) shows how domestic price is determined. Import tariffs are charged based on the c.i.f. (cost insurance freight) price of timber, which is shown by $\mathrm{P}_{\mathrm{w}}$ in the above equations. Equation (2) shows how per unit import tariff is calculated. GST per unit of product is based on c.i.f. price of timber and per unit tariff. Equation (3) shows how GST per unit is calculated. Per unit rate of NDL is based on a number of factors and equation (4) explains how it is calculated. Conceptually, the demand function $D=f\left(P_{d}\right)$, supply function $\mathrm{S}=\mathrm{g}\left(\mathrm{P}_{\mathrm{d}}\right)$, trade identity, import $=D-S$, and price linkage identity, $P_{d}=P_{w}+$ Tariff $+G S T+N D L$, form the structure of the model. The D, S, import and $\mathrm{P}_{\mathrm{d}}$ in the above system of equations are endogenous variables. The exogenous variables, Tariff $\%$, GST\%, NDL\%, and $\mathrm{P}_{\mathrm{w}}$, and the coefficient of the supply and demand functions determine the values of these endogenous variables.

Impact of liberalization of border charges and other local taxes can be analyzed by examining the changes in $\mathrm{D}, \mathrm{S}$, imports and $\mathrm{P}_{\mathrm{d}}$ due to changes in the values of border charges and taxes. Hereafter, we call all the distortions (border charges and taxes) "border charges". Figure 2 shows the impacts due to reduction of border charges. With the reduction of border charges, domestic price will go down from $\mathrm{P}_{\mathrm{d}}$ to $\mathrm{P}_{\mathrm{d}}$, , and depending upon the elasticities of demand and supply, quantity demanded will increase from $\mathrm{D}$ to D' and local supply will decrease from S to S'. Imports will increase from (D-S) to (D'-S'). As a result of the changes in quantity demanded, quantity supplied and prices, benefits and costs to different market participants will change. In this simple framework, the social welfare is measured in terms of changes consumer and producer surplus. We do not attempt to calculate the theoretically correct welfare measures; compensated variation and equivalent variation here. We assume Willig's (1976) bound are applicable and hence, consumer and producer surpluses approximate welfare changes adequately. Removal of border charges will change the government revenue too. 
However, here we consider that the government revenue from timber trade is distributed to consumers as lump-sum transfers and therefore, no net impact on the social welfare. With the removal of the border charges, consumer surplus will increase by an area $(a+b+c+d)$ and producer surplus will decrease by an area $a$. Area $(b+d)^{1}$ represents the net welfare gain due to removal of a border charge.

Figure 2: $\quad$ Effect of timber trade liberalization

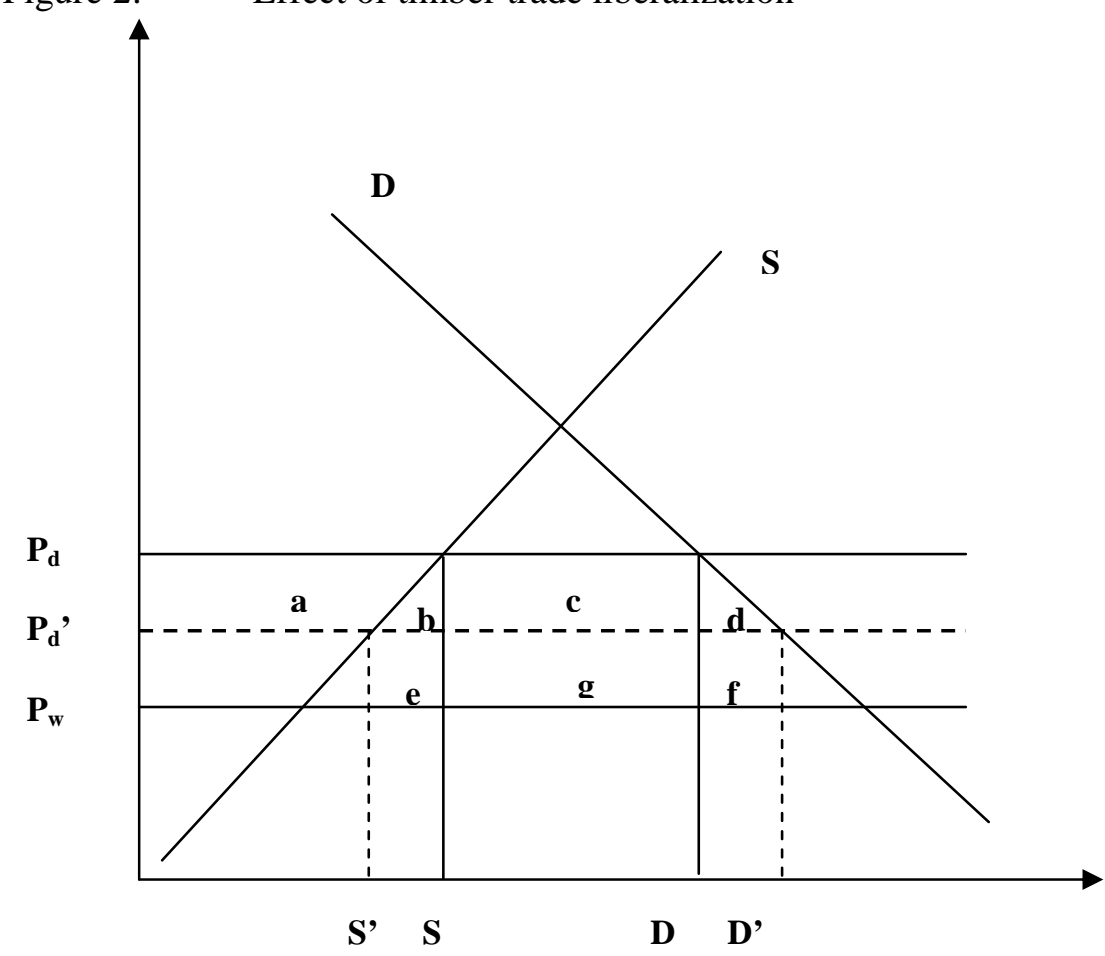

\footnotetext{
${ }^{1}$ Note that consumer surplus of timber consumers is increased by $(a+b+c+d)$. However, government tariff revenue, which will subsequently transfer to the consumers will decline by $c$. By construction, this model predicts a gain in social welfare due to removal of one or more border charges. The size of the welfare gain is primary determined by the elasticities of demand and supply with respect to price.
} 


\section{Empirical Model}

One of the problems encountered in simulating the above model was the construction of the supply and demand equations for sawn wood. A thorough literature survey indicates that estimates of timber demand and supply elasticities for Sri Lanka are not available. Time series data required to estimate the demand and supply functions were not available too. Further searches indicated that similar estimate for South Asian Countries are not available. Table 1 shows some of the available elasticities estimated for other countries. These elasticities are not indicative as to what range of values are appropriate for Sri Lanka. Therefore, the above model was calibrated using baseline data set for year 1999 for three different sets of elasticities; elastic, unitary elastic, and inelastic demand and supply. Baseline data and elasticity values used are given in Tables 2 and 3, respectively.

First, the equilibrium in year 1999 was reproduced. Linear demand and supply curves were assumed, and intercept and slope of the demand and supply functions were generated using baseline values reported in Table 2 and elasticity values reported in Table 3. Then import tariff, goods and services tax and national defense levy were eliminated to observe the counterfactual equilibrium.

Welfare measures were calculated using the changes in demand, supply, price and import quantity. Government revenue in terms of tariff, GST revenue and NDL revenue were also calculated separately. Total social welfare was obtained by adding government revenue, consumer surplus and producer surplus. 
Table 1: $\quad$ Price elasticities of demand for timber

\begin{tabular}{|c|c|c|c|c|}
\hline Source & Period & Countries & Products & Elasticities \\
\hline \multirow[t]{2}{*}{ Bourke } & \multirow{2}{*}{1988} & \multirow{2}{*}{$\begin{array}{l}\text { Japanese import from } \\
\text { developing countries }\end{array}$} & Sawn timber & -1.3 \\
\hline & & & Veneer and Plywood & -1.8 \\
\hline Brooks & $1971-91$ & United States imports & Hard wood & -1.2 \\
\hline Cardellichio & \multirow[t]{9}{*}{$1965-87$} & N.America/W.Europe & & -0.5 \\
\hline \multirow{8}{*}{ et al. } & & Japan & Non-Coniferous & -2.42 \\
\hline & & Korea & Sawn wood & -1.06 \\
\hline & & N.America/W.Europe & & -0.3 \\
\hline & & Japan & Coniferous sawn wood & -0.67 \\
\hline & & Korea & & -1.51 \\
\hline & & United States & & -0.5 \\
\hline & & Japan & Non-coniferous & -0.55 \\
\hline & & Korea & Plywood & -0.85 \\
\hline \multirow[t]{5}{*}{$\mathrm{ECE} / \mathrm{FAO}$} & \multirow[t]{5}{*}{$1964-81$} & Group one countries France & & -0.46 \\
\hline & & Germany & Sawn wood & -0.28 \\
\hline & & Netherlands & & -0.34 \\
\hline & & Switzerland & & -1.07 \\
\hline & & United Kingdom & & -0.49 \\
\hline \multirow[t]{3}{*}{ Kallio et al. } & \multirow[t]{3}{*}{1987} & Countries with per capita & Non-coniferous sawn w. & -1.2 \\
\hline & & income above & Coniferous sawn wood & -0.5 \\
\hline & & US\$ 3,000? & Veneer and Plywood & -0.4 \\
\hline Meyer & $1952-75$ & Switzerland & Industrial wood & -1.4 \\
\hline NEI & $1961-81$ & $17 \mathrm{~W}$-Euororean countries & Tropical timber & -0.34 \\
\hline Slangen & $1963-81$ & Netherlands & Coniferous sawn wood & -0.78 \\
\hline \multirow[t]{3}{*}{ Wibe } & \multirow[t]{3}{*}{$1970-79$} & 60 countries with per capita & Non-coniferous sawn w. & -1.19 \\
\hline & & income above US\$2500 in & Coniferous sawn wood & -0.54 \\
\hline & & 1975 & Wood panels & -0.18 \\
\hline
\end{tabular}

Source: ITTO, (1993).

Table 2:

Baseline data set

\begin{tabular}{llc}
\hline Variable & \multicolumn{1}{c}{ Units } & Value \\
\hline Demand & Cubic meters & 613,700 \\
Supply & Cubic meters & 558,400 \\
Domestic Price & USD/cubic meter & 311.60 \\
Border charges & $\%$ & \\
$\quad$ Import Tariff & & 10.00 \\
$\quad$ Goods and Services Tax & & 12.50 \\
$\quad$ National Defence Levy & & 6.50 \\
\hline
\end{tabular}


10

Table 3: $\quad$ Elasticities of demand and supply with respect to own price

\begin{tabular}{lcc}
\hline & Supply & Demand \\
\hline Elastic & 1.25 & -1.25 \\
Unitary elastic & 1.0 & -1.0 \\
Inelastic & 0.5 & -0.5 \\
\hline
\end{tabular}

\section{Results and Discussion}

Table 4 presents the impacts of elimination of import tariff; GST, NDL together under the assumption of elastic price response. In Table 4, GOVT, CS, PS and SW refer to government revenue, consumer surplus, producer surplus and social welfare respectively. GOVT is calculated by summing revenue from import tariff, GST and NDL. SW is calculated by summing GOVT, CS and PS. Results for inelastic demand and supply, and unitary demand and supply are given in the Appendix. As predicted by the theoretical model, the results show that all the cases of liberalisation of border charges will lead to higher demand, lower local supply, lower prices and higher social welfare. The magnitude of the changes, however, depends on the elasticity.

Table 4: $\quad$ Impacts of removal of all border charges under elastic demand and supply

\begin{tabular}{lcccc}
\hline Units & Base Case & $\begin{array}{c}\text { Removal of all } \\
\text { border charges }\end{array}$ & $\begin{array}{c}\text { Percentage } \\
\text { Change }\end{array}$ \\
\hline Demand & $\mathrm{M}^{3}$ & 613,700 & 802,680 & 30.79 \\
Supply & $\mathrm{M}^{3}$ & 558,400 & 386,448 & -30.79 \\
Imports & $\mathrm{M}^{3}$ & 55,300 & 416,232 & 652.68 \\
Price & $\mathrm{USD}^{3} \mathrm{M}^{3}$ & 311.6 & 234.84 & -24.63 \\
Tariff & USD million & 1.29 & 0 & -100.00 \\
GST & USD million & 1.78 & 0 & -100.00 \\
NDL & USD million & 0.16 & 0 & -100.00 \\
GOVT & USD million & 4.24 & 0 & -100.00 \\
Consumer & USD million & 76.49 & 130.85 & 71.06 \\
Surplus & & & & \\
$\begin{array}{l}\text { Producer } \\
\text { Surplus }\end{array}$ & USD million & 69.60 & 33.33 & -52.10 \\
Social & & & & \\
Welfare & USD million & 150.33 & 164.19 & 9.21 \\
\hline
\end{tabular}


Table 5 shows the summary results of simulations. The highest social welfare increase $9.21 \%$ was observed for the case of elastic demand and supply while the lowest was $1.49 \%$ observed for the inelastic demand and supply. The results thus show that actual magnitudes of the social welfare changes depend heavily on the elasticity values. Recall that we did not use very high elasticity (absolute) values in our simulations. Had we used such values, we would have observed much higher welfare changes.

Table 5: Welfare changes due to timber market liberalization under different elasticity assumptions*

\begin{tabular}{lll}
\hline Scenario & \multicolumn{1}{c}{$\begin{array}{c}\text { Local supply } \\
\mathbf{M}^{\mathbf{3}}\end{array}$} & \multicolumn{1}{c}{$\begin{array}{c}\text { Social welfare } \\
\text { USD million }\end{array}$} \\
\hline Inelastic demand \& supply: & \multicolumn{1}{c}{} \\
Base & 558,400 & 369.478 \\
Counterfactual & $489,619(-12.31 \%)$ & $375.019(+1.49 \%)$ \\
\hline Unitary elastic demand \& supply: & 558,400 & 186.862 \\
Base & $420,838(-24.63 \%)$ & $197.94(+5.93 \%)$ \\
Counterfactual & & \\
\hline Elastic demand and supply: & 558,400 & 150.33 \\
Base & $386,448(-30.79 \%)$ & $164.19(+9.21 \%)$ \\
Counterfactual & & \\
Elastic demand and inelastic & & \\
supply: & 558,400 & 254.74 \\
Base & $489,619(-12.31 \%)$ & $264.63(+3.88 \%)$ \\
Counterfactual & & \\
\hline Inelastic demand \& elastic supply: & 558,400 & 265.07 \\
Base & $386,448(-30.79 \%)$ & $274.58(+3.58 \%)$ \\
Counterfactual &
\end{tabular}

* Figures in parenthesis are percentage changes from the base values.

Policy changes, in most of the circumstances, result in gains to some groups and loses to others. As the results show, the removal of distortions increase consumer surplus due to lower prices and thus the consumers are the gainers of the timber market liberalisation. The same lower prices will reduce the local supply and producer surplus. Thus, timber producers are the losers in timber market liberalisation. Overall, the gains of consumers are higher than the loses incurred by producers. Therefore, this policy experiment passes the potential compensation test. However, it is necessary to look at the losers more carefully and analyse their situation from the equity point of view. In the case of timber, however, there is no organised timber producing sector in Sri 
Lanka. Some of the multipurpose trees harvested from the home gardens supply part of the timber. Rest of the timber come to the market from natural forests and that are harvested through various illegal activities. In the case of timber from natural forests, there are hardly any resource rents. The way this timber is harvested does not allow collection of any royalties. In the case of private lands like the home gardens, timber producers are gaining a minimum return while timber traders and government officers extract most of the rents.

Table 6 shows the formation of final timber prices based on a survey conducted in Moneragala district of Sri Lanka. As shown by the data in the table, only about $20 \%$ of the final value of timber goes to timber producers, while timber traders take about $60 \%$ of the final value as profits. Unofficial transaction costs (UOTC) in the table refers to the bribers paid by timber traders to the government officials who handle timber permits. Given the difficulty in obtaining the data on this aspect, the percentage contributed by the UOTC can be much higher than what is presented in the table. As explained by Senaviratne and Gunatilake (2001) in their study, most of the resource rents are dissipated as unofficial transactions cost and profits of the timber traders. Since most of the rents of timber go to rent seeking government officers and timber traders, producers are not actual losers in the case of timber trade liberalisation in Sri Lanka.

With this view in mind, the welfare increase due to timber trade liberalisation in Sri Lanka should only include the consumers' gains. Table 7 presents the consumer welfare increases under different elasticity scenario. Annual consumer surplus increase, as shown in the table, is about US\$ 40 million, which is comparatively much higher than that of trade liberalisation in the agriculture sector. According to Ratnasiri et al., (1999) change in consumer surplus due to $10 \%$ reduction in price due to trade liberalization in potato, onion, and chillie sectors are US\$ 2.67, 3.41 and 4.23 million respectively (see Table 8). 
13

Table 6: $\quad$ Formation of the market price of timber

\begin{tabular}{lrrrrrr}
\hline Item & $\begin{array}{l}\text { Satin } \\
\text { wood }\end{array}$ & \multicolumn{1}{l}{ Jak } & Teak & Kolon & Average Percentage \\
\hline Owners price & 224.97 & 100.00 & 136.88 & 128.19 & 147.51 & 22.20 \\
Pruning of & 3.81 & 3.82 & 3.81 & 3.81 & 3.81 & 0.57 \\
branches & & & & & & \\
Cutting \& logging & 10.33 & 10.33 & 10.33 & 10.33 & 10.33 & 1.55 \\
Depot & 5.96 & 6.58 & 5.96 & 5.96 & 6.12 & 0.92 \\
Loading & 10.33 & 10.33 & 10.33 & 10.33 & 10.33 & 1.55 \\
Transport & 38.20 & 38.20 & 36.67 & 36.67 & 37.44 & 5.63 \\
UOTC* & 60.91 & 44.85 & 44.85 & 44.85 & 48.87 & 7.35 \\
Profit Margin & 425.49 & 486.52 & 451.17 & 218.00 & 395.30 & 59.49 \\
Final price & 800.00 & 700.00 & 700.00 & 458.00 & 664.50 & 100.00 \\
\hline
\end{tabular}

* UOTC refers to unofficial transaction costs

Table 7: $\quad$ Gains in consumer surplus under different demand elasticities (USD Million)

\begin{tabular}{lccc}
\hline Scenario & Base case & $\begin{array}{c}\text { Counterfactual } \\
\text { equilibrium }\end{array}$ & Change in CS \\
\hline Inelastic demand & 191.23 & 231.27 & $40.04(20.94 \%)$ \\
$\begin{array}{l}\text { Unitary elastic } \\
\text { demand }\end{array}$ & 95.61 & 137.56 & $41.95(43.87 \%)$ \\
Elastic demand & 76.49 & 119.39 & $42.90(56.08 \%)$ \\
\hline
\end{tabular}

Table 8: $\quad$ Estimated on impacts on consumer welfare due to Trade Liberalisation in agriculture ${ }^{1}$ (USD million)

\begin{tabular}{lcrcc}
\hline Study & Commodity & $\begin{array}{c}\text { Gain in } \\
\text { Consumer } \\
\text { Surplus }\end{array}$ & $\begin{array}{c}\text { Loss in } \\
\text { Producer } \\
\text { Surplus }\end{array}$ & $\begin{array}{c}\text { Welfare } \\
\text { Gain }\end{array}$ \\
\hline Ratnasiri et al., & Potato & 2.67 & 1.23 & n.a \\
$(1999)^{2}$ & Onion & 3.41 & 0.48 & n.a \\
& Chillie & 4.27 & 0.02 & n.a \\
Weerahewa et al., & Potato & 36.99 & 26.54 & 10.44 \\
$\begin{array}{l}\text { (2000) } \\
\text { Rafeek and }\end{array}$ & Rice & 4.63 & 1.16 & 3.19 \\
Samaratunga (2000) & & & & \\
\hline
\end{tabular}

${ }^{1}$ Exchange rate: 72.18 Rs/US\$ in 1999.

${ }^{2}$ Change in government revenue is not reported. 
Sometimes, the general welfare gains from trade liberalization are overlooked in favour of losses to a certain group. For example, in the case of potato trade liberalisation in Sri Lanka, consumers gained enormous benefits compared to producers' loss of social welfare (Weerahewa et al., 2000). In that case although there were much higher gains to consumers than loses to potato producers, much attention was paid to the fate of producers. Reintroduction of some non-tariff barriers for potato in Sri Lanka shows how political pressures influence the trade policy actions regardless of the fact that such actions are economically inefficient. However, the case of timber trade liberalisation is quite different and one can safely ignore the welfare losses of the producers given the current institutional set up under which local timber trade takes place.

As described earlier in this paper, the producer surplus losses due to timber trade liberalization is not a true cost to the timber producers. Given this reasoning, if one ignores the reduction of the producer surplus, the gains in consumer surplus seems substantial. The other major welfare loss is government revenue loss, which is US\$ 3.43 million. However, this loss is not very significant as it is only $0.126 \%$ of the total government revenue of US\$2716 (Central Bank of Sri Lanka, 2000).

From the perspective of the protection of natural forests, there are two major impacts of timber trade liberalisation. First, it will reduce the local timber price significantly. As shown in the Appendix tables, price will drop by $25 \%$. Such a price drop will certainly reduce incentives for illegal logging. Illegal loggers consider the expected value of the cost of being caught and punished against the expected benefits. A price decrease would reduce the expected benefits and, depending on the degree of risk acceptance, some of the illegal loggers' expected cost will exceed the expected benefit as timber prices drop with trade liberalisation. Although we were not able to quantify the impact of potential log price drop, the price reduction reduces the illegal logging.

The other impact of timber market liberalisation on forest comes through reduction in local supply. As evident from the results, local supply of sawn wood reduces by $24.93 \%, 19.94 \%$ and $9.97 \%$ under the elastic, unitary elastic and inelastic demands. In order to highlight the impact of reduction of local supply, these supply reduction figures were converted to hectares of natural forest saved under some plausible assumptions. The following 
assumptions were made in converting the saved logs to natural forests. The data used in this calculation was taken from MFE (1995).

1) On average, the different types of natural forests provide the following wood volumes:

Lowland rain forests: $126 \mathrm{~m}^{3} / \mathrm{ha}$

Dry monsoon forests: $21 \mathrm{~m}^{3} / \mathrm{ha}$

Moist monsoon forests: $39 \mathrm{~m}^{3} / \mathrm{ha}$

Of these forest types lowland rainforests are confined to few patches and they are protected. Wood harvest from this type of forests is practically least feasible. Moist monsoon forests are also limited to small areas. Only dry monsoon forests remain in large areas and illegal logging largely takes place in this category of forests. Therefore, the saved forests are calculated assuming that a weighted average of $25.5 \mathrm{~m}^{3}$ of wood can be harvested from one $h a$ of forests. In this calculation the weights of dry monsoon forests and moist monsoon forests were assigned the weights of 3 and 1 , respectively.

2) Total local sawn wood supply is $558,400 \mathrm{~m}^{3}$ per year in year 2000 . Of this volume of sawn wood it was suggested from the results that $24.93 \%$, $19.94 \%$ and $9.97 \%$ could be saved under elastic, unitary elastic and inelastic demand scenarios, respectively.

3) Assuming a recovery rate of $40 \%$ in the saw milling industry, the saved sawn wood volumes were converted to saw logs. Then these log volumes were converted to ha of natural forests assuming that $1 \mathrm{ha}$ of natural forest provides $25.5 \mathrm{~m}^{3}$ of logs.

Table 9 shows the potential prevention of deforestation due to timber trade liberalisation. In a similar study Gunatilake and Gunaratne (2001) estimated the technical efficiency in the saw milling sector using a stochastic production frontier model. Their results suggest that on average, sawmills are $27 \%$ inefficient. Further, this study shows that technical efficiency is determined by age of the machines, log quality, type of management, entrepreneurship ability of the manager, mill size and type of operation. With the same assumptions, Gunatilake and Gunaratne predicted possible savings of natural forest with technical efficiency improvement. Table 10 shows the results. 
16

Table 9: $\quad$ Timber market liberalisation and prevented deforestation

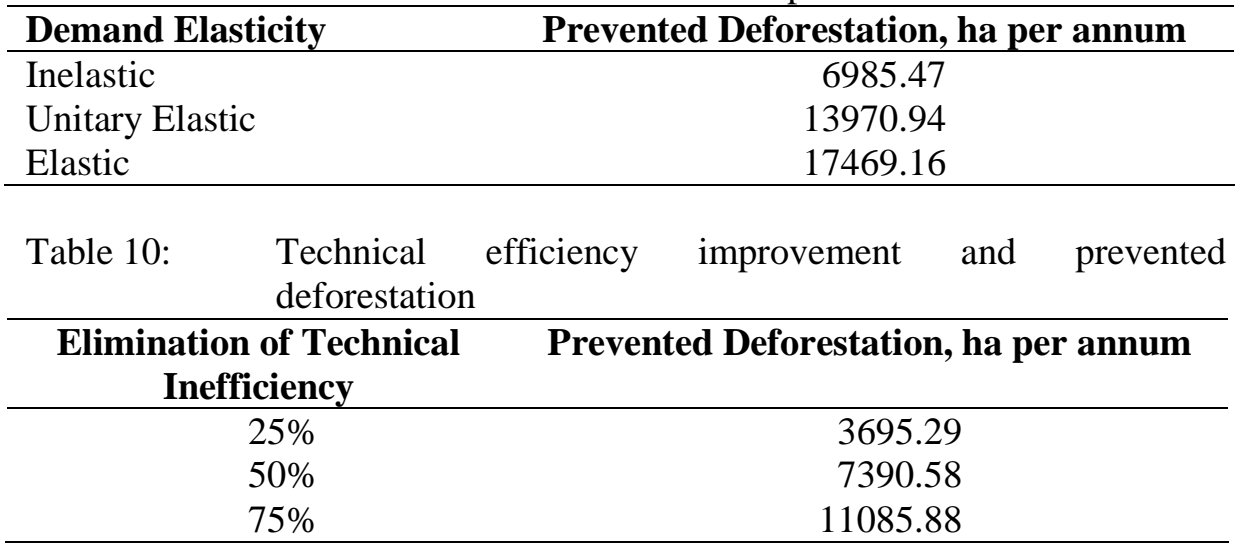

As shown by this analysis, timber market liberalisation seems to be a superior option compared to the improvement of technical efficiency, in terms of reducing deforestation in Sri Lanka. As the numbers indicate, timber market liberalisation can save more forest lands compared to efficiency improvement. Further, as the analysis on determinants of technical efficiency shows, there are many factors affecting technical efficiency. Controlling these factors to improve efficiency through policy changes seems difficult (Gunatilake and Gunaratne, 2001). Moreover, trade liberalisation improves social welfare while eliminating inefficiency. It may or may not increase social welfare depending on the costs and benefits involved. For example, if the old machines are replaced with costly new machines, the benefits of efficiency improvements have to be weighed against the costs. Given these reasons, timber trade liberalisation seems to be an attractive option in reducing deforestation in Sri Lanka.

Forestry is a long-term activity and therefore, effects of many policy changes will be observed only after 30-40 years. For example, if necessary policy changes are implemented today to remove existing disincentives for plantation forestry by private sector, its impact can be observed only after a long time. Similarly, many measures to improve technical efficiency will have their impact after so many years. Trade liberalisation, compared to these measures has the advantage of immediate effectiveness. However, from a global perspective, the wood imports have to come from somewhere. If the exporting country has sustainably managed forest plantations, it may not cause problems in the supplying country. However, if the imported wood is 
coming from natural forests of the supplying country, it is necessary to make sure that the wood harvesting system has minimum impact on biodiversity and other forest services. If the exporting country has an unsustainable forest industry, trade liberalization would only be transferring the environmental impact from one country to the other. If this aspect is checked properly, timber market liberalization will help in protecting natural forests in Sri Lanka, while enhancing the overall welfare of people.

\section{Summary and Conclusions}

This study examined the impact of timber market liberalization on welfare and forest conservation in Sri Lanka. Sri Lanka underwent a rapid phase of deforestation during the last century. Forest cover declined significantly as a result and some of the important forest types remain as small patches. Protection of these forests is important for the provision of environmental services such as biodiversity. The protected forests and unprotected forests in the country are interdependent. Unprotected forests should be properly managed to supply forest products such as timber. Existing regulations do not allow timber extraction from natural forests. However, illegal logging activities are taking place in unprotected forests and these forests are already heavily degraded. If proper policies are not implemented to augment timber supply in the country, these illegal activities will spread to the protected forests too.

Given the above-described interdependency, it is important to look for alternatives to meet the timber requirements of the country. This study examined the prospects of timber trade liberalization on prevention of deforestation in Sri Lanka. A partial equilibrium market simulation model was used for the analysis. Given the lack of demand and supply data, the model was simulated with plausible elasticity values. The results show that timber market liberalization reduces the local price by about 25\%. This price reduction will reduce the incentives for illegal logging. Further, the price reduction increases consumer welfare by about US\$ 40.00 million per year. Given that there is no organized timber-supplying sector and timber rents from the private lands are extracted by rent seeking government officers and timber traders, loss of producer surplus is not a true welfare loss. Welfare gain due to timber trade liberalization seems to be higher than those opportunities in the agriculture sector. Revenue loss by the government is comparatively 
small and therefore, government may not hesitate to implement timber trade liberalization.

Depending on the supply and demand elasticities, timber trade liberalization reduced local timber supply by about $12-30 \%$. This reduction was converted to natural forest area with plausible assumptions. The results show that timber trade liberalization saves about 6985, 13971 and $17469 \mathrm{ha}$ of forest lands under inelastic, unitary elastic and elastic demand and supply, respectively. Compared to the similar savings of natural forests through technical efficiency improvements, timber trade liberalization seems to provide better results. Effectiveness in the short run, significant welfare improvement, lack of losers and donor community's support make timber trade liberalization an attractive option for protection of natural forests in Sri Lanka.

\section{References}

Central Bank of Sri Lanka (1996). Annual Report. Central Bank of Sri Lanka, Sri Lanka.

Central Bank of Sri Lanka (2000). Annual Report. Central Bank of Sri Lanka, Sri Lanka.

Central Bank of Sri Lanka (2001). Annual Report. Central Bank of Sri Lanka, Sri Lanka.

Gunatilake, H.M. and L.H.P. Gunaratne (2001). Policy Options for Protecting Natural Forests in Sri Lanka. A Report Submitted to Economy and Environment Program for Southeast Asia.

Gunatilleke, I.A.U.N. and C.V.S. Gunatilleke (1991). Threatened Woody Endemics of Wet Lowlands of Sri Lanka and their Conservation. Biological Conservation, 55: 17-36.

ITTO (1993). The Economic Linkages Between the International Trade in Tropical Timber and the Sustainable Management of Tropical Forests: Technical Annexes to the Main Report to he ITTO. International Timber Trade Organization. 
Kotagama H.B., S. Ranawana, S. Vidanage and U. Dahanayake (1997). Role of Economic Valuation, Environmental Impact Assessment, the Sri Lankan Experience. USAID/SL Natural Resource and Environmental Policy Project, Centre for Environmental Studies, University of Peradeniya,

MFE (1995). Sri Lanka Forestry Sector Master Plan. Forestry Planning Unit, Ministry of Forestry and Environment (MFE), Sri Lanka.

Rafeek, M.I.M. and P.A. Samaratunga (2000). Trade Liberalization and its Impact on the Rice Sector of Sri Lanka. Sri Lankan Journal of Agricultural Economics, 3(1): 143-154.

Ratnasiri, S., R. Marasinghe and J. Weerahewa (1999). Economic Impact of Trade Liberalization for Other Field Crops in Sri Lanka. Tropical Agricultural Research, 11: 255-271.

Senaviratne, J. and H.M. Gunatilake (2001). Can Regulation of Timber Trade Protect our Forests? An Unpublished Report, Department of National Planning, Colombo, Sri Lanka.

Weerahewa, J., H.M. Gunatilake, S. Thrikawela, and H.B. Kotagama (2000). Impact of Potato Trade Liberalisation on Soil Erosion: A MultiPeriod Market Simulation Model. Sri Lankan Journal of Agricultural Economics, 3(1): 123-141.

Willig, R.D. (1976). Consumer's Surplus without Apology. American Economic Review, 66(4): 589-597.

World Bank (1993). Strategy for Forest Sector Development in Asia. World Bank Technical Paper, No. 182: Washington DC. 


\section{Appendix}

Table A1: $\quad$ Impact of removal of all border charges under inelastic demand and supply

\begin{tabular}{lcccr}
\hline Units & Base Case & $\begin{array}{c}\text { Removal of all } \\
\text { border charges }\end{array}$ & $\begin{array}{c}\text { Percentage } \\
\text { Change }\end{array}$ \\
\hline Demand & $\mathbf{M}^{3}$ & 613,700 & 689,292 & 12.31 \\
Supply & $\mathbf{M}^{3}$ & 558,400 & 489,619 & -12.31 \\
Imports & $\mathbf{M}^{3}$ & 55,300 & 199,673 & 261.07 \\
Price & USD/ M & 311.60 & 234.84 & -24.63 \\
Tariff & USD million & 1,298 & 0.00 & -100.00 \\
GST & USD million & 1.785 & 0.00 & -100.00 \\
NDL & USD million & 1.160 & 0.00 & -100.00 \\
GOVT & USD million & 4.245 & 0.00 & -100.00 \\
CS & USD million & 191.23 & 241.24 & 26.15 \\
PS & USD million & 174.00 & 133.77 & -23.11 \\
SW & USD million & 369.47 & 375.02 & 1.49 \\
\hline
\end{tabular}

Table A2: $\quad$ Impact of removal of all border charges under unitary elastic demand and supply

\begin{tabular}{lcccr}
\hline Units & Base Case & $\begin{array}{c}\text { Removal of all } \\
\text { border charges }\end{array}$ & $\begin{array}{c}\text { Percentage } \\
\text { Change }\end{array}$ \\
\hline Demand & $\mathrm{M}^{3}$ & 613,700 & 764,884 & 24.63 \\
Supply & $\mathrm{M}^{3}$ & 558,400 & 420,838 & -24.63 \\
Imports & $\mathrm{M}^{3}$ & 55,300 & 344,046 & 522.14 \\
Price & USD/ M & 311.60 & 234.84 & -24.63 \\
Tariff & USD million & 1.298 & 0.00 & -100.00 \\
GST & USD million & 1.785 & 0.00 & -100.00 \\
NDL & USD million & 0.160 & 0.00 & -100.00 \\
GOVT & USD million & 4.245 & 0.00 & - \\
& & & & 100.00 \\
CS & USD million & 95.61 & 148.52 & 55.33 \\
PS & USD million & 87.00 & 49.41 & -43.20 \\
SW & USD million & 186.86 & 197.94 & 5.93 \\
\hline
\end{tabular}

